\title{
The differential sensitivity of red pine and quaking aspen to competition
}

\author{
Klaus J. Puettmann and Peter B. Reich
}

\begin{abstract}
Growth of red pine (Pinus resinosa Ait.) and quaking aspen (Populus tremuloides Michx.) target trees with varying degrees of competition by neighboring aspen was measured in a 7-year-old clearcut in northeastern Minnesota. Competitive conditions were measured using indices of resource availability (percent open sky) and neighborhood stand density. Three-year diameter growth of target trees was reduced by more than $50 \%$ in both species because of competition from neighboring quaking aspen. The last 2 year's height growth was also reduced by approximately $30 \%$ for both species. The relationship between growth and percent open sky was convex for red pine and concave for quaking aspen, potentially indicating a greater sensitivity in aspen to any reduction below optimal resource availability. Competition reduced crown size in both species, but self-pruning occurred only in quaking aspen. Needle and leaf size were not affected by competition, but red pine needle density was lower in highly competitive environments. Red pine had a higher specific gravity when growing under competition, partially offsetting the reduction in wood volume.
\end{abstract}

Résumé : La croissance d'arbres-cibles, des pins rouges (Pinus resinosa Ait.) et des peupliers faux-tremble (Populus tremuloides Michx.), soumis à divers degrés de compétition par les peupliers avoisinants a été mesurée dans une coupe à blanc de 7 ans dans le nord-est du Minnesota. La compétition a été caractérisée à l'aide d'indices de disponibilité des ressources (pourcentage d'ouverture du couvert) et de densité des peuplements voisins. La croissance en diamètre sur 3 ans des arbres-cibles a été réduite de plus de 50\% chez les deux espèces à cause de la compétition des peupliers faux-tremble voisins. La croissance en hauteur des 2 dernières années a aussi été réduite d'environ $30 \%$ chez les deux espèces. La relation entre la croissance et le pourcentage d'ouverture du couvert était convexe chez le pin rouge et concave chez le peuplier faux-tremble, indiquant possiblement que le peuplier est plus sensible à toute réduction de la disponibilité des ressources en dessous d'une valeur optimale. La compétition a réduit la dimension de la cime chez les deux espèces mais l'élagage naturel s'est produit seulement chez le peuplier faux-tremble. La dimension des aiguilles et des feuilles n'étaient pas affectée păr la compétition mais la densité des aiguilles du pin rouge était plus faible dans les milieux hautement compétitifs. Le pin rouge avait un poids spécifique plus élevé lorsqu'il croissait en situation de compétition, ce qui compensait partiellement pour la réduction du volume de bois.

[Traduit par la Rédaction]

\section{Introduction}

A number of research studies have compared species in competitive environments, trying to generalize competitive ability by growth habit (Goldberg and Landa 1992) and (or) successional status (Tilman 1988; Bazzaz 1990). Competition can be separated into two components (Goldberg 1990), the ursupation or preemption of a resource pool and the response of plants to a resource pool that has been preempted by competitors. Foresters traditionally have used shade tolerance ratings for trees (Baker 1949), assuming that the tolerance ratings are an expression of the response to the environment (Daniel et al. 1979). However,

Received November 21, 1994. Accepted May 11, 1995.

K.J. Puettmann and P.B. Reich. Department of Forest Resources, 115 Green Hall, University of Minnesota, St. Paul, MN 55108, U.S.A. direct studies are lacking that examine whether tolerance ratings are related to the response to a limited resource pool (sensitivity to competition) rather than the ability to preempt a resource pool.

Red pine (Pinus resinosa Ait.) is a major species in the managed forests of the Lake States. It is considered an intolerant species (Baker 1949; Rudolf 1990), and recent studies indicated that the growth pattern is affected by resource availability (Elliott and White 1993). Quaking aspen (Populus tremuloides Michx.) is a very shade-intolerant species (Perala 1990) that mostly regenerates through suckering after cutting in managed forests. Its fast initial growth makes quaking aspen a strong competitor in red pine plantations. Competition from aspen has been found to lead to significant growth reductions or even failure of red pine plantations (Perala 1990). The recent development of new markets for quaking aspen, such as paper production, has increased the interest in aspen management. We chose 
these species because of their wide overlapping distributions, contrasting behavior, economic importance, and co-occurrence in red pine plantations. Based on the tolerance ratings we expect quaking aspen to show greater sensitivity than red pine to competition.

While White and Elliott (1992) found that competitor leaf area index (LAI) strongly influenced red pine growth irrespective of competitor species, they noted that competitor LAI is difficult to measure directly. They suggested that competitor LAI is more easily estimated indirectly using field instruments such as the LAI 2000 (LI-COR Inc.) or the Decagon ceptometer. We choose a slightly different approach to seeking easily measured means to estimating competition. Rather than estimating LAI within a radius of the target tree (which ignores height of the competitor plants and their distance from the target) we estimated the impact of competitor leaf area on the resource availability to each target tree, measured as percent open sky (POS) in a $76^{\circ}$ cone upwards from the target individual (see Howard and Newton 1984; Pretsch 1992). While the POS measurement is based on light penetration, it can be assumed that the trees that contribute to heavy overtopping also compete intensively for belowground resources. Thus we are using POS as an index of the overall competitive pressure experienced by the target trees rather than solely of light interference.

The overall objective of this study was to characterize and contrast the response of red pine and quaking aspen target trees to competition from neighboring aspen. Specific objectives included to (i) quantify and compare competitive effects on red pine and quaking aspen diameter and height growth, (ii) evaluate the effects of competition on crown size, self-pruning, and foliar density within the crown, (iii) compare the effects of competition on leaf and needle morphology, and (iv) determine whether wood density is affected by competition.

\section{Methods}

The study site was located on the Cloquet Forestry Center, Cloquet, Minn., on a Cloquet Series fine sandy loam. It was clear-cut in 1986 and planted with 2-1 red pine seedlings at 2.4-m spacing in the spring of 1987. Seedling survival was very high, but aspen suckers appeared, and after two growing seasons the site was evenly occupied with quaking aspen. A herbicide trial released part of the clearcut by spraying randomly located $7.5 \mathrm{~m}$ wide strips with Velpar $^{\circledR}$ or Pronone ${ }^{\circledR}$ in fall of 1987 or spring of 1988. This resulted in differential release, as indicated by $5-100 \%$ quaking aspen mortality in the treatment strips (ButlerFastland 1990). The resulting stand thus contained a gradient from open-grown red pine to red pine that were completely overtopped by a group of aspen. Alternatively, free-standing quaking aspen could be found as well as quaking aspen that were overtopped by a group of neighboring aspen.

We selected 39 red pine and 38 quaking aspen as target trees using a stratified sampling design to ensure the coverage of the full range of competitive conditions (opengrown trees to trees overtopped by neighboring aspen). Random points were established, and the nearest tree that
Table 1. Size of red pine and quaking aspen target trees at the time of treatment in spring 1988.

\begin{tabular}{lcc}
\hline & $\begin{array}{c}\text { Diam. in 1987 } \\
(\mathrm{mm})\end{array}$ & $\begin{array}{c}\text { Height in 1987 } \\
(\mathrm{cm})\end{array}$ \\
\hline Red pine & 6.9 & 59.1 \\
& $(3.0)$ & $(16.1)$ \\
Quaking & 6.9 & na \\
aspen & $(2.9)$ & \\
\hline
\end{tabular}

Note: Values are means with standard deviations given in parentheses. na, not available.

was fairly open growing and the nearest tree that was overtopped by quaking aspen were chosen as target trees. Target trees were selected to be free of diseases, even though minor herbivory and aspen twig blight (Venturia tremula) could not be avoided.

Measurements of target trees in August 1992 included total height and the diameter at $30 \mathrm{~cm}$ height (not all trees had reached breast height). A summary of the tree size after planting is presented in Table 1 . While the past 5 year's height could be measured with accuracy for 25 red pine, quaking aspen tree height could only be determined for the current and last 2 years. After all other measurements were made, disks were cut at $30 \mathrm{~cm}$ height and the diameter of previous years was measured. Since compression wood is a result of random factors (e.g., animal damage) and has a higher density, disks that had obvious signs of compression wood were eliminated from the analysis, leaving 24 red pine and 37 quaking aspen disks for which ovendry specific gravity was determined. Current and last year's crown size were determined by measuring the current and last year's width of the crown at the widest point and perpendicular to the widest point. Both measurements were averaged and, assuming a circular crown shape, the average diameter was used to calculate crown area. Together with the height to the base of the crown and tree height, crown volume for the last 2 years was calculated, assuming a cone shape. Sections of branches were cut from the lower, middle, and upper portion of the crown, and the branch length, number of fascicles or leaves, and the leaf area were measured for each branch section.

As a measure of competitive conditions we measured light availability, which is a function of overtopping, during August 1992. An integrating light sensor (LAI 2000, LI-COR Inc.) using a $76^{\circ}$ cone was placed upwards at the base of last year's height growth during times when the sky was uniformly overcast. The leaders of the target trees were bent to avoid interference of the target trees. Light penetration at this point was compared with a simultaneous measurement in open condition. By integrating the gap fractions the proportion of the sky that was not blocked by foliage (percentage of open sky; POS) was calculated. POS was then used to compare the trees in terms of their relative light availability. Also, height and diameter of all trees within a $2-\mathrm{m}$ radius around the target tree were measured. In addition, height and diameter were measured for all 
trees that were farther than $2 \mathrm{~m}$ from the target tree whose crowns reached into the cone used for the POS measurements. Data analysis used linear and nonlinear regression of the SAS statistical package (SAS Institute Inc. 1987).

\section{Results and discussion}

A variety of competitive indices have been developed ranging from sophisticated mathematical models to simple ocular estimation of percent cover. Because of the difficulty in measuring resource levels, most competition measures are based on the amount of and, in some cases, location of neighboring vegetation and assume that these measures are related to the reduction in resources that drive competition (Wagner and Radosevich 1991). For example, the degree of overtopping by neighboring plants, either measured directly or by the amount of light that is received by target plants, has been found to be related to the performance of the target plants (Howard and Newton 1984; Jobidon 1992). The POS as determined by the LAI 2000 is a simple, quick index of overtopping that allows a comparison of the competitive pressure that trees experience. This index is based on a composite of the number and location of competing plants and the size differences between target and competing neighbor plants. Both of these components have been used successfully in competition studies (Kropff et al. 1992; Lindquist et al. 1994). To test whether variation in microsites or the herbicide application was more important in determining current POS, we regressed POS over different neighborhood variables. POS was significantly but weakly positively related to the mean height $\left(R^{2}=0.18, p<0.001\right)$ and the mean diameter $\left(R^{2}=0.07, p<0.001\right)$ of neighboring aspen. However, the density (number of aspen) in the neighborhood explained the highest portion of variation in $\operatorname{POS}\left(R^{2}=0.45, p<0.001\right)$ (Fig. 1). Regression lines using a combination of these variables did not show an improvement in fit. The positive correlation between plant density and competitive pressure as measured by POS suggests that the herbicide treatments are mainly responsible for the differential competitive conditions in the plant neighborhoods. If other factors, like self-thinning, would have been more influential, this correlation would be not significant or inverse.

Since initial size difference can impact growth and development of trees in plantations, we tested whether the target trees within either species were the same size at the time of treatment. We examined whether the current competitive conditions are related to initial differences in height (red pine only) and diameter (both species). Both red pine and quaking aspen showed no significant relationship between diameter in fall of 1987 and current POS measurements $(p=0.11$ and 0.16 , respectively, with negative slopes). Also, red pine height at the time of release (1987) was not related to current POS ( $p=0.78)$. Thus the herbicide treatments were applied to a homogenous study area, and current competitive conditions are due to treatment effects, rather than to microsite differences or initial differences in size.

\section{Growth}

The growth of a tree is related to both its initial size and competitive conditions. To separate these effects the size at
Fig. 1. Percent open sky (POS) in a $76^{\circ}$ cone above the target tree as a function of quaking aspen density (DEN) within a $2-\mathrm{m}$ circle (POS $\left.=100-1.1 \mathrm{DEN}, R^{2}=0.45\right)$.

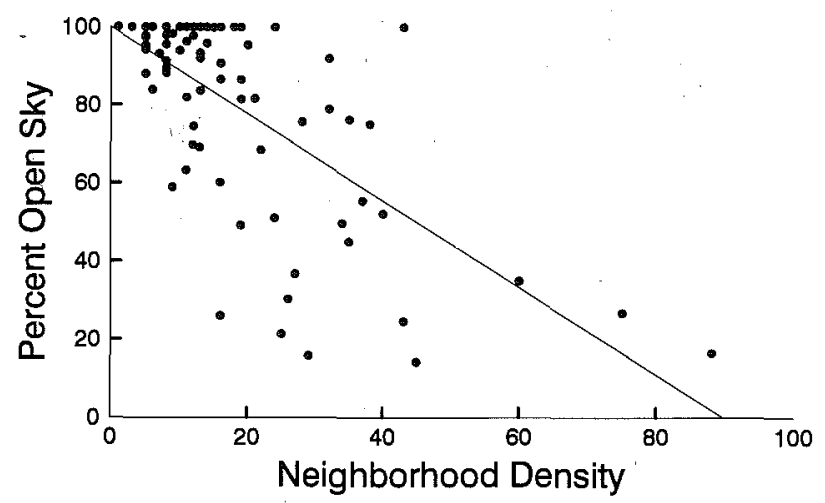

the beginning of each of the last five growing seasons was regressed against current POS. The last year in which the diameter of both species was not significantly correlated with the current competitive conditions was in spring 1990. The last year that height of red pine was not significantly related to current POS was in spring of 1991. The lack of significant relationships in earlier years might be due to the inaccuracy of using current POS to estimate competitive conditions 4 and 5 years ago. Alternatively, it can be expected that growth of the seedlings in their first years after outplanting might be more affected by nursery practices or planting effects, especially if competitive pressure was not very high. For these reasons, the first 2 year's diameter and first 3 year's height growth were not included in the analysis. In a comparable study on two sites, red pine showed a reduction in diameter growth resulting from woody competition after the first 2 years only on the better quality site (White and Elliott 1992). Our results indicate that this might not necessarily be due to solely a sitequality effect, but might also be due to a time effect. On lower quality sites, where seedlings grow more slowly, effects may not be detectable for several years.

Diameter growth has been shown to be sensitive to competitive conditions (Zutter et al. 1986; Brand 1990; Morris et al. 1990). In our study, both red pine and quaking aspen diameter growth was influenced by the competitive status of the trees. Residual analysis of linear regressions, which showed similar fits as nonlinear regressions, indicated the need to use nonlinear equations (Neter et al. 1983).

Three-year red pine diameter growth was correlated with POS in a nonlinear fashion with a convex shape (the slope parameter was significantly lower than 1 with $p<0.001$ ) (Fig. 2a). POS explained more than half of the variation in 3-year diameter growth $(p<0.001)$. Lieffers and Stadt's (1994) analysis of leader growth as a function of light transmittance indicates that white spruce (Picea glauca (Moench) Voss), a moderately tolerant species, exhibits a similar-shaped relationship. Quaking aspen diameter growth in the last 3 years showed a concave relationship to competitive conditions in plant neighborhoods (Fig. $2 b ; p=0.001$ ). In both species, increasing competition, expressed as POS from 100 to $20 \%$, caused a greater than $50 \%$ reduction in diameter growth. 
Fig. 2. Three-year diameter growth (DG) at $30 \mathrm{~cm}$ of (a) red pine (DG $\left.=21.26 \mathrm{POS}^{0.02}, R^{2}=0.58\right)$ and (b) quaking aspen (DG $=1.92 \exp (0.02 \mathrm{POS}), R^{2}=0.38$ ) as a function of percent open sky (POS).

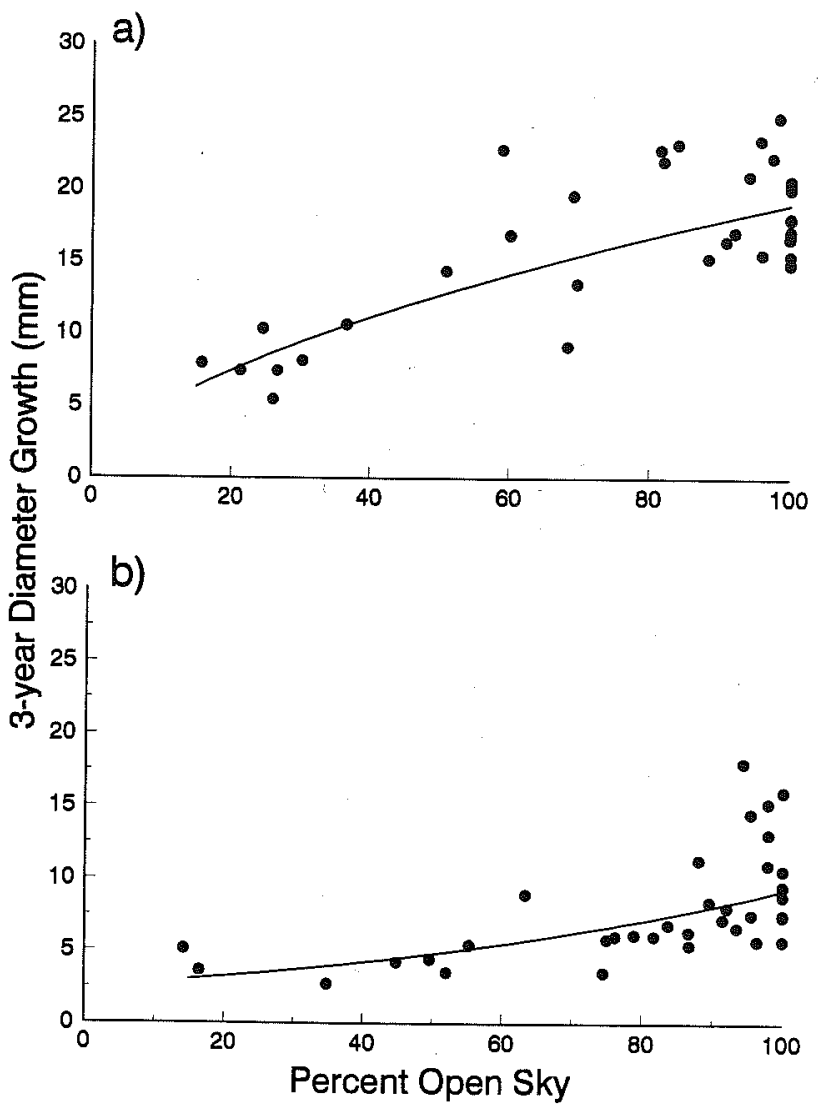

While height growth generally does not show a consistent response to competition (Stone 1980; Zutter et al. 1986; Brand 1990; Morris et al. 1990), red pine and quaking aspen height growth the last 2 years was significantly reduced by competitive pressure $(p<0.001$ and $p=0.023$, respectively) (Fig. 3). Several hypotheses might explain why red pine height growth in 1991 was not related to current POS, while diameter growth during that year was. Height growth is generally considered to be very insensitive to density conditions (Smith 1986). Alternatively, for determinate species, growing conditions in the previous year are partially responsible for height growth in the current year. Thus, a delayed response is to be expected for red pine (Sucoff 1971). In two cases, effects of competition by grass and shrubs (Young et al. 1993) and other woody vegetation (White and Elliott 1992) were not detected the first 2 years. The authors discuss several hypotheses for the lack of response in their studies. Our results support their hypothesis that competition might not have been strong enough in the first year.

Only the last 2 year's height growth could be determined with accuracy for quaking aspen. While significantly correlated with current $\operatorname{POS}(p=0.023)$, the equation explains only a minor portion of the variation in the height growth during the last 2 years. This might be due to
Fig. 3. Two-year height growth (HG) of red pine as a function of percent open sky (POS) for $(a)$ red pine $\left(\mathrm{HG}=91.5 \mathrm{POS}^{0.05}, R^{2}=0.48\right)$ and $(b)$ quaking aspen $\left(\mathrm{HG}=42.2 \exp (0.05 \mathrm{POS}), R^{2}=0.12\right)$.

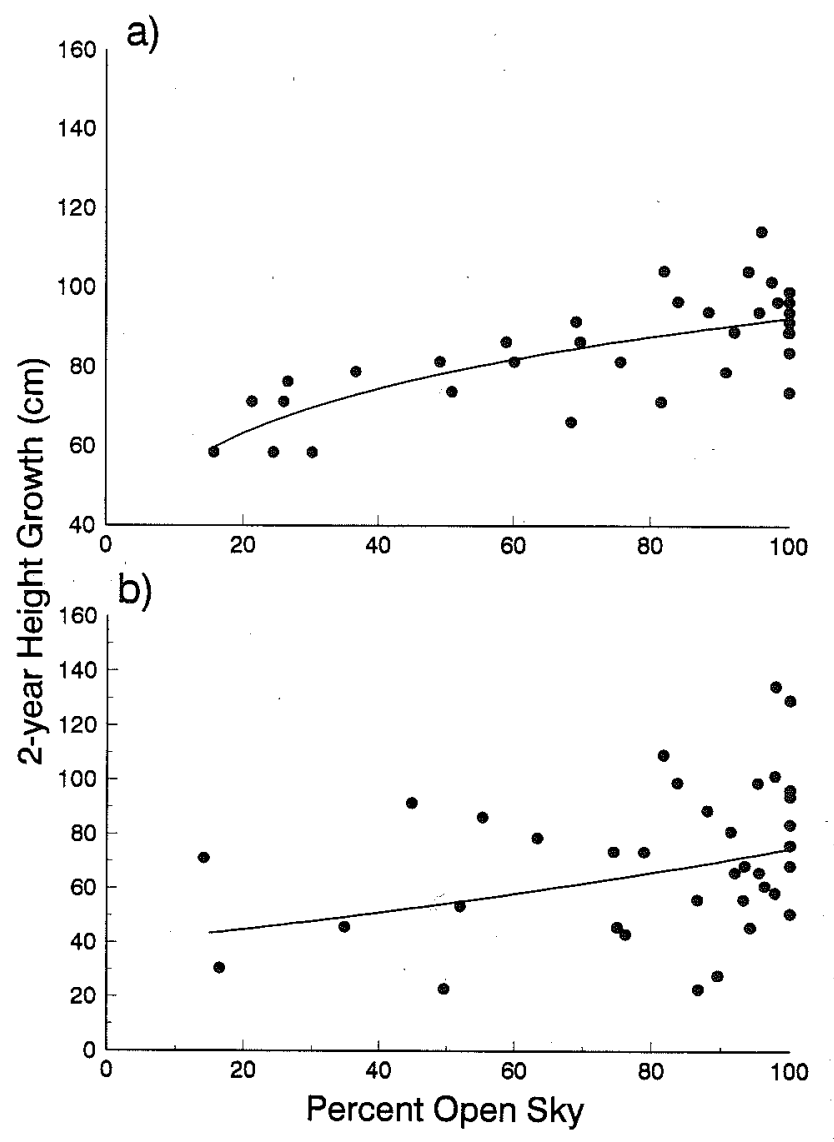

partial loss of the leader to sheppard's crook. Alternatively, quaking aspen on the study site originated from suckering, and during the initial years the possibility of a nutrient or hormone transfer between suckers exists (D.A. Perala, unpublished data). A lingering effect of a potential transfer through the root system would cloud the effect of competition on growth, resulting in lower $R^{2}$ values for quaking aspen than for red pine.

Self-pruning has been associated with competition in dense stands (Giordano and Hibbs 1993). Height to the bottom of the crown of red pines, however, was constant across the competitive gradient $(p=0.70)$. Competition from aspen was not yet severe enough to lead to mortality of the lower branches. Even in red pine monocultures, crown recession starts at a fairly late age (e.g., 15 years at 1.2-m spacing) (Larocque and Marshall 1993). However, the height to the bottom of the crown $(\mathrm{CH})$ of quaking aspen target trees increased linearly with higher competition $\left(\mathrm{CH}=163.7-0.62 \mathrm{POS}, R^{2}=0.22\right.$ and $\left.p=0.003\right)$. Aspen branch mortality is more sensitive to competition, indicating that the self-pruning can be a very efficient method of ensuring a clean stem and high-quality wood boles in aspen stands.

Crown volume growth in 1992 for both red pine and quaking aspen was affected by competition and showed 
Fig. 4. Crown volume increment (CG) in 1992 of $(a)$ red pine $\left(\mathrm{CG}=0.138 \mathrm{POS}^{0.63}, R^{2}=0.25\right)$ and $(b)$ quaking aspen $\left(\mathrm{CG}=5.38 \exp (0.012 \mathrm{POS}), R^{2}=0.11\right)$ as a function of percent open sky (POS).

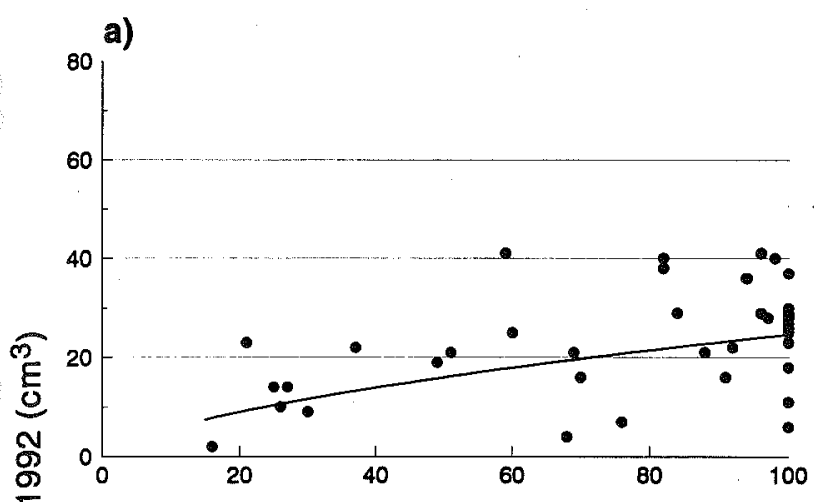

b)

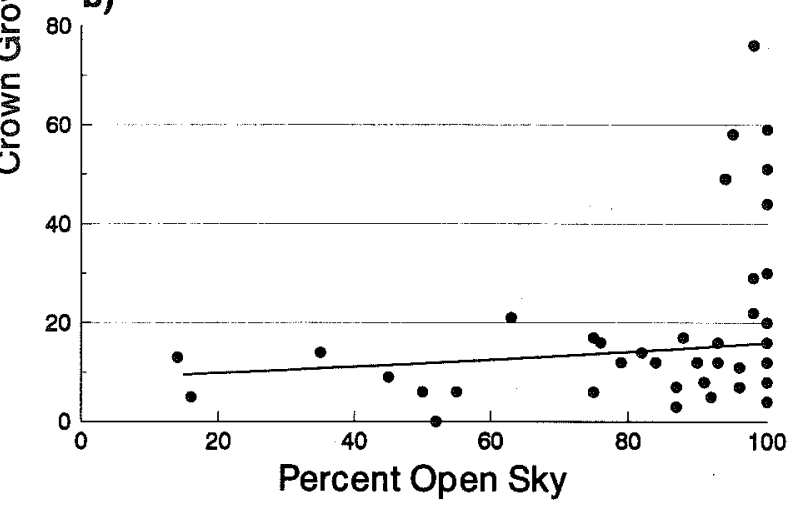

the same nonlinear shapes as found for height and diameter growth (Fig. 4). Crown growth of quaking aspen seems to increase gradually but showed accelerated growth when POS was over $90 \%$ (Fig. $4 b$ ), resulting in a relatively poor $R^{2}$ of 0.11 . While the increased crown size in red pine is due to height and crown area expansion, the crown growth of quaking aspen is also affected by mortality of the lower branches. Loss of crown volume due to self-pruning is more than offset by the increased crown area growth in a lowcompetition environment. Since the size of the crown is usually a good indicator of the growth potential (Stiell and Berry 1977), differences in crown size are partially responsible for differences in height and diameter growth in the most recent years. It can be assumed that the tendency to further separate the growth trends as a function of competitive status will continue.

One difference between the two species is the concave and convex shape of the relationship between POS and diameter growth for quaking aspen and red pine, respectively (see also Lieffers and Stadt 1994). While the exact equation form might be subject to further investigations, the possibility that these patterns might constitute a more general phenomenon warrants discussion. A convex relationship would imply that initial deviations from optimal conditions have a minor effect. However, as the conditions worsen, the effect on growth increases. A concave shape would imply that a minor deviation from the optimal
Fig. 5. Specific gravity (SG) of red pine wood disks cut at $30 \mathrm{~cm}$ height as a function of percent open sky (POS) $\left(\mathrm{SG}=0.388-0.00037 \mathrm{POS}, R^{2}=0.23\right.$ ).

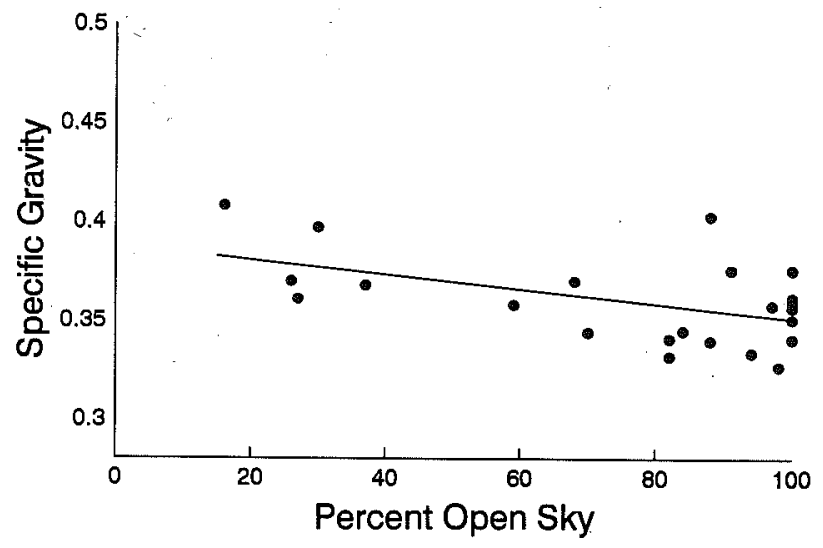

conditions results in a relatively greater reduction from optimal growth. Further deviations from optimal conditions have less effect. Thus, a convex relationship would be expected for a less intolerant species (e.g., red pine), and a concave relationship for a more intolerant (e.g., quaking aspen) species.

The possibility of nonlinear growth response patterns that are not consistent across species might become critical, when only limited treatment levels (e.g., herbicide treated and untreated) are used in competition studies and data are analyzed by measuring seedlings within a larger treatment plot and calculating the average response. Arithmetic averages assume a linear relationship. Using mean values when the treatment is not homogenous throughout the plot would lead to under- or over-estimation of growth for species with a convex or concave relationship, respectively, at intermediate competitive levels. Also, the exact level used to separate competitive conditions into distinct groups (e.g., above or below $60 \%$ light penetration in Jobidon 1992) might be of critical importance and can potentially influence the results.

\section{Morphology}

The average needle length of red pine was not affected by competition ( $p=0.83$ ), but fascicle density (number of fascicles per centimeter of branch) decreased with increasing competition (fascicle density $=5.68+0.24 \mathrm{POS}$, $\left.R^{2}=0.32 p=0.0002\right)$. Quaking aspen did not show the same trend. The average leaf size of aspen $(p=0.17)$ and the density of leaves along a branch section (number of leaves divided by the length of the branch section) were not affected by competition $(p=0.73)$. Our results contradict the findings of Strothman (1967) and Caldwell (1987), who determined red pine needle length to be affected by shading or competition for water. Both authors measured the needles the first 2 years after exposing them to competition. The number of needles is determined in the previous growing season in trees with determinate growth patterns, leaving only their size to be affected by competition in the current year. Plants that have been growing under competitive conditions for several years, as on our study site, had time to adjust to their growing conditions. 
Most studies measure the effect of competition on size of plants (Grace and Tilman 1990), but competition might also affect quality of plant material. A quality measure of commercial interest for both species is wood density, measured as specific gravity. It is related to the amount of pulp per unit wood (Zobel et al. 1973), and even small decreases in specific gravity (e.g., $2 \%$ ) are estimated to significantly increase pulping costs (Kellog 1982). To obtain sufficient-sized samples the disks that were used for measurement of specific gravity could not be separated into growth rings, rather the entire wood disks were used in our study. Thus the data presented provide an average over the full life-span of trees. There is no reason to suspect that specific gravity differed among the trees in the first years of their life. Thus, differences in specific gravity for the whole disk must be driven by the wood laid down in the last few years. This would indicate that the mean values are actually underestimating specific gravity differences in the last few years. Red pine stem sections had a higher specific gravity as competition slowed growth $(p=0.016)$ (Fig. 5). Eliminating one disk that contained a minute portion of compression wood lowers the $R^{2}$ to 0.15 and increases the $p$-value to 0.072 . On the other hand, the specific gravity of quaking aspen was not affected by competitive conditions. Earlier thinning studies do not show a consistent trend relating higher growth rate to a reduced proportion of latewood and thus lower wood density in several conifers (Zobel and van Buijtenen 1989). Zaner and Oliver (1962) found that the latewood proportion of red pine, which strongly affects specific gravity, was not affected by thinning. Ignoring the change in wood density would lead to overestimation of the effects of competition on wood biomass (a function of volume and density) of red pine by up to $15-20 \%$. This might be crucial in comparisons of ecosystem productivity and in the decision about the need for release treatment in plantations, even though differences in specific gravity might only be temporary (Cown 1974; Shepard and Shottafer 1992; Barbour et al. 1994). Alternatively, genetic studies in quaking aspen have found that growth rates of quaking aspen are not correlated with specific gravity (G.W. Wycoff, unpublished data). The results indicate the importance not only to investigate the effects of competition on volumetric measure but also to include aspects of plant quality.

\section{Acknowledgements}

We appreciate the financial support of the Wilderness Research Foundation and the Minnesota Agricultural Experiment Station as well as the help from the Forest Vegetation Management and Aspen-Larch Cooperatives, University of Minnesota, St. Paul.

\section{References}

Baker, F.S. 1949. A revised tolerance table. J. For. 47: 179-181

Barbour, R.J., Fayle, D.C.F., Chauret, G., Cook, J., Karsch, M.B., and Ran, S. 1994. Breast-height relative density and radial growth in mature jack pine (Pinus banksiana) 38 years after thinning. Can. J. For. Res. 24: 2439-2447.

Bazzaz, F.A. 1990. Plant-plant interactions in successional environments. In Perspectives on plant competition. Edited by
J.B. Grace and D. Tilman. Academic Press, New York. pp. 239-264.

Brand, D.G. 1990. Growth analysis of response by planted white pine and white spruce to changes in soil temperature, fertility, and brush competition. For. Ecol. Manage. 30: 125-138.

Butler-Fastland, M. 1990. Forest Vegetation Management Cooperative 1989 annual report. University of Minnesota Press, St. Paul.

Caldwell, J.M. 1987. Grasses competing with red pine seedlings for water, nutrients, and light. M.S. thesis, University of Minnesota, St. Paul.

Cown, D.J. 1974. Comparison of the effect of two thinning regimes on some wood properties of radiata pine. For. Sci. 4: $540-551$.

Daniel, T.W., Helms, J.A., and Baker, F.S. 1979. Principles of silviculture. 2nd ed. McGraw-Hill, New York.

Elliott, K.J., and White, A.S. 1993. Effects of competition from young northern hardwoods on red pine seedling growth, nutrient use efficiency, and leaf morphology. For. Ecol. Manage. 57: 233-255.

Giordano, P.A., and Hibbs, D.E. 1993. Morphological response to competition in red alder: the role of water. Funct. Ecol. 7: $462-468$.

Goldberg, D.E. 1990. Components of resource competition in plant communities. In Perspectives on plant competition. Edited by J.B. Grace and D. Tilman. Academic Press, New York. pp. 27-50.

Goldberg, D.E., and Landa, K. 1992. Competitive effect and response hierarchies and correlated traits in the early stages of competition. J. Ecol. 79: 1013-1030.

Grace, J.B., and Tilman, D. (Editors). 1990. Perspectives on plant competition. Academic Press. New York.

Howard, K.M., and Newton, M. 1984. Overtopping by successional Coast-Range vegetation slows Douglas-fir seedlings. J. For. 82: 178-180.

Jobidon, R. 1992. Measurement of light transmission in young conifer plantations: a new technique for assessing herbicide efficacy. North. J. Appl. For. 9: 112-115.

Kellog, R.M. 1982. Coming to grips with wood quality. For. Chron. 57: 254-257.

Kropff, M.J., Weaver, S.E., and Smith, M.A. 1992. Use of ecophysiological models for crop-weed interference: relations amongst weed density, relative time of weed emergence, relative leaf area, and yield loss. Weed Sci. 40: 296-301.

Larocque, G.R., and Marshall, P.L. 1993. Evaluating the impact of competition using relative growth rate in red pine (Pinus resinosa Ait.) stands. For. Ecol. Manage. 58: 65-83.

Lieffers, V.J., and Stadt, K.J. 1994. Growth of understory Picea glauca, Calamagrostis canadensis, and Epilobium angustifolium in relation to overstory light transmission. Can. $\mathbf{J}$. For. Res. 24: 1193-1198.

Lindquist, J.L., Rhode, D., Puettmann, K., and Maxwell, B.D. 1994. The effect of spatial arrangement on individual plant yield. Ecol. Appl. 4: 518-524.

Morris, D.M., McDonald, G.B., and McClain, K.M. 1990. Evaluation of morphological attributes as response variables to perennial competition for 4-year-old black spruce and jack pine seedlings. Can. J. For. Res. 20: 1696-1703.

Neter, J., Wassermann, W., and Kutner, M.H. 1983. Applied linear regression analysis. Irwin, Homewood, Ill.

Perala, D.A. 1990. Quaking aspen. In Silvics of North America. Vol. 2. Hardwoods. Edited by R.M. Burns and B.H. Honkala. U.S. Dep. Agric. Agric. Handb. 654. pp. 555-569.

Pretsch, H. 1992. Konzeption and Konstruktion von Wuchsmodellen für Rein-und Mischbestände. University of Munich, Munich, Germany. Forstl. Forschungsber. 115. 
Rudolf, P.O. 1990. Red pine. In Silvics of North America.. Vol. 1. Conifers. Edited by R.M. Burns and B.H. Honkala. U.S. Dep. Agric. Agric. Handb. 654. pp. 442-455.

SAS Institute Inc. 1987. SAS/STAT guide for personal computers, version 6 edition. SAS Institute Inc., Cary, N.C.

Shepard, R.K., and Shottafer, J.E. 1992. Specific gravity and mechanical property - age relationships in red pine. For. Prod. J. 42: 60-66.

Smith, D.M. 1986. The practice of silviculture. John Wiley \& Sons, New York.

Stiell, W.M., and Berry, A.B. 1977. A 20-year trial of red pine planted at seven spacings. Can. For. Serv. For. Manage. Inst. Inf. Rep. FMR-X-97.

Stone, D.M. 1980. Survival and growth of red pine planted on a hardwood site - a second look. For. Chron. 56: 112-114.

Strothman, R.O. 1967. The influence of light and moisture on the growth of red pine seedlings in Minnesota. For. Sci. 13: $182-191$.

Sucoff, E. 1971. Timing and rate of bud formation in Pinus resinosa. Can. J. Bot. 49: 1821-1832.

Tilman, D. 1988. Plant strategies and the dynamics and structure of plant communities. Princeton University Press, Princeton, N.J.
Wagner, R., and Radosevich, S. 1991. Neighborhood predictors of interspecific competition in young Douglas-fir plantations. Can. J. For. Res. 21: 821-828.

White, A.S., and Elliott, K.J. 1992. Predicting the effects of hardwood competition on red pine seedling growth. Can. J. For. Res. 22: 1510-1515.

Young, M.J., Johnson, J.E., and Thiel, D.A. 1993. Effects of paper mill sludge and weed control on competing vegetation and growth of young red pine. New For. 7: 345-364.

Zaner, R., and Oliver, W.W. 1962. The influence of thinning and pruning on the rate of summerwood initiation in red and jack pines. For. Sci. 8: 51-63.

Zobel, B.J., and van Buijtenen, J.P. 1989. Wood variation. Its causes and control. Springer-Verlag, Berlin.

Zobel, B.J., Kellison, R.C., and Kirk, D.G. 1973. Wood properties of young loblolly and slash pine. Effect of growth acceleration on wood properties. USDA Forest Service, Forest Products Laboratory Madison, Wis.

Zutter, B.R., Gjerstad, D.H., and Glover, G.R. 1986. Effects of herbaceous weed control using herbicides on a young loblolly pine plantation. For. Sci. 32: 882-889. 